\title{
Corrupt desires and the wages of sin: Indigenous people, missionaries and male sexuality, 1830-1850
}

\section{Jessie Mitchell}

In 1841, Reverend Francis Tuckfield of the Buntingdale mission near Geelong, Victoria, recorded a conversation he had recently had with a group of Aboriginal men. The men were impressed by a new hut being built on the mission and announced to Tuckfield that they wanted huts of their own, but these would have to be spacious, to accommodate their three wives each. Tuckfield told them sternly that if they wanted the material benefits of European housing they should also adopt the moral benefits of European monogamy. The men were more puzzled than offended by Tuckfield's lecture on the sin of polygamy, and asked with surprise why God would be interested in such an ordinary matter and why He would deny the privilege of multiple wives even to the missionaries who talked so much about Him. They rejected Tuckfield's suggestion that they abandon two wives each, explaining, much to his outrage, that they needed lots of women to do their hard work. Tuckfield felt his worst fears had been confirmed: the men, he believed, had no respect for women or monogamy, not so much because of lust, but because of laziness, greed and amorality - these, the missionary assumed, were typical qualities of savages. ${ }^{l}$

Tuckfield, like his fellow missionaries, was attempting to impart Christian sexual morality to Aboriginal people, a task that provoked reactions ranging from curiosity and confusion to determined opposition. Such encounters formed an important part of daily life on missions and protectorate stations in New South Wales and Port Phillip during the early nineteenth century. The 1830s and 1840s - an era when violence, dispossession and Indigenous depopulation occurred alongside enthusiastic humanitarian endeavour — saw interesting developments in Aboriginal-missionary relations. Aboriginal people, while impoverished and traumatised by invasion, were not yet under strong government control, and retained many elements of pre-colonial life. The roles of evangelical Protestant missionaries and government-appointed protectors were also at a unique stage. Although missionaries' power as colonising agents would increase greatly in the twentieth century, during these early decades they still lacked economic power, strong government support or social acceptance in the Australian colonies. The first protectors - most of whom had strong religious backgrounds and saw their job largely in missionary terms - had government backing but inadequate physical power or social support. ${ }^{2}$ They trod an uneasy balance between enticing 
Aborigines to their stations and trying to discipline them when they arrived. The relationships they formed arguably relied as much on negotiation and exchange as they did on coercion. The limited power of these early humanitarians has led many historians to focus largely on the reasons for their failure, ${ }^{3}$ an approach which is unfortunate, as it does not consider the complex encounters and relationships that developed between Aboriginal people and the first protectors and missionaries. Missionaries' lack of strong authority made these encounters all the more intricate, marked by a mixture of arrogant paternalism, cultural bewilderment and reluctant accommodation.

One particular area generally neglected by historians is the attitude of these early missionaries and protectors towards Aboriginal men's sexuality. This is a topic worth exploring both because of the immediate impact of missionary activities on Aboriginal people's lives and also because missionary and protectorate writings helped to shape British and colonial attitudes - mostly amongst religious humanitarian communities - towards Aboriginal humanity and future potential. This brief study considers missionaries' and protectors' concerns about Aboriginal men's sexual behaviour — real and imaginary including desires for black and white women and other men and involvement in prostitution. These views, in turn, must be situated within general European ideas of 'black' or 'native' men as sexually deviant, ideas that took a particular shape in the early Australian colonies. Some forms of sexual 'deviance' attracted more missionary attention than others, arguably because of their perceived relevance to broader questions about Aboriginal men's economic and social roles. Aboriginal responses to missionary civilising agendas at this time were largely pragmatic but nonetheless varied, and their reactions to these particular campaigns of sexual civilisation encompassed tolerance, opportunism, angry opposition and bored rejection.

Recently there has been growing interest in how white Australia has represented and exploited Aboriginal women's sexuality, a topic explored by historians including Patricia Grimshaw, Susan Hunt, Mary Anne Jebb, Anna Haebich, Ann McGrath and Patty O'Brien. ${ }^{4}$ There has not really been any equivalent body of work produced on European portrayals of the sexuality of Aboriginal men, however, particularly during this early colonial period. Some historians claim that Indigenous men have been commonly depicted as brutally lustful savages, hyper-masculine in their sexual aggression but lacking masculine self-control (identified as a European quality). Patty O'Brien, Jan Pettman, Anna Haebich and Raymond Evans point out that these stereotypes were used to rationalise European men's economic and political dominance and acquisition of Aboriginal women and land. These historians stress the particular importance to colonial agendas of stories about Aboriginal men posing a sexual threat to white women. ${ }^{5}$ These historians consider the issue only briefly, however, focusing largely on popular colonial stereotypes from the late nineteenth and 
early twentieth centuries. An examination of sexual politics on the first missions and protectorate stations reveals rather different sexual ideas, emerging from a different intellectual and social climate.

Belief in the sexual savagery of non-European men predated the colonisation of Australia. By the sixteenth century, ancient European folk myths of wild men of the woods - described as animalistic, filthy, violent and promiscuous were being reshaped and racialised by the medieval custom of depicting devils as black men and the circulation of European travellers' stories of Africa as a place of wild, unregulated sex. ${ }^{6}$ However, the expansion of the slave trade and European imperialism, combined with growing European interest in natural history and human biology, must be seen as essential in encouraging these initially vague and unsystematic ideas of black male sexual savagery to become much more common, vicious and biologically determinist, keeping pace with intellectual trends and rationalising developing colonial power structures. ${ }^{7}$

Given missionaries' and protectors' ambiguous place within the power structure of colonial Australia - as aggressive cultural colonisers and self-avowed Christian philanthropists - their sexual agendas become particularly interesting. Unlike settlers, the first missionaries and protectors had little desire to dehumanise Aborigines or portray them as a doomed, impotent race. Nor did they wish to justify sexual relationships between European men and Aboriginal women. Rather, as evangelical Christian colonisers, they were particularly concerned about sexual immorality and keen to implement systems of bodily and mental surveillance and control. They sometimes portrayed Aboriginal societies as promiscuous, probably referring to both traditional practices of polygamy and bestowing women, and colonial prostitution. Protector James Dredge, working in Taungurong country along the Goulbourn River in the 1840s, described 'sins of the most obscene and revolting description, alike destructive to the body and to the soul' ${ }^{8}$ Rev William Watson of the Wellington Valley mission in Wiradjuri country in the 1830s deplored Aborigines' 'corrupt desires' and 'lowest and most obscene' practices, and Rev James Günther's wife, Lydia, was disgusted by their 'vile wretched habits and moral degradation'. 9 In most of these cases, the immoral desires seem to have been implicitly attributed to men; while missionaries often considered Aboriginal women degraded and corrupt, they rarely credited them with enough free will to determine their own sexual behaviour.

When the first missionaries and protectors discussed Aboriginal men's lusts, they usually referred to desire for Aboriginal women. The possibility of sexual relationships between Aboriginal men was a topic missionaries and protectors mentioned only occasionally. Given this scarcity, it is difficult to say exactly how such behaviour (real or imagined) was viewed, but some suggestions can be made. Living in an era before firm medical, legal or social definitions of 
homosexuality in Europe, missionaries generally did not imply that such sexual behaviour made certain Aboriginal men inherently strange and marginalised, or that these men necessarily lacked masculinity. Rather, the 'awful crime of "Sodomy", 10 as missionaries characterised it, was depicted as a degenerate heathen act rather than a permanent identity. When travelling around Wellington Valley, missionary JCS Handt was surprised and disturbed when a party of young Wiradjuri men and boys refused to follow him to the mission, despite his talking to them about God and giving them pipes and tobacco. He concluded (with an intriguing leap of logic) that the men must have wished to keep the boys to 'commit with them the horrid sin of Sodom'. ${ }^{11}$ Protector Edward Stone Parker of the Loddon River district in Port Phillip also suspected that 'unnatural offences are not uncommon among these degraded people ... most of the single men are guilty of this horrible crime ... the young boys are brutally forced to become their victims' ${ }^{12}$ As with the prostitution of Aboriginal women, missionaries and protectors varied between blaming original heathen sin and corrupt European influences. Handt blamed such behaviour on Aboriginal customs, saying of male initiation at Moreton Bay 'such filthy acts attend the whole of the ceremony as are best buried in silence'. ${ }^{13}$ Chief Protector GA Robinson, in contrast, was more inclined to blame settlers. When travelling in the Goulbourn River district, he saw boys being offered to white stockmen 'for the purpose of committing unnatural offence' and was told 'plenty of white fellows on the Goulbourn always did that'. ${ }^{14}$ Parker, similarly, blamed the European removal of Aboriginal women, since, he said, this 'crime' was only committed by single men, who stopped once they were married. ${ }^{15}$

Whether these stories were true or not, they indicate a particular European view of male sexuality. The emphasis on sodomy as a sinful act rather than an intrinsic identity squares with what Robert Aldrich, Craig Johnston and Robert Johnston have identified as general concerns about convicts' sexual behaviour in early colonial Australia. Sex between men was depicted as a degrading criminal act to be eradicated through physical punishment, not necessarily a symptom of any radically different sexual or gender identity. ${ }^{16}$ These missionary accounts are also suggestive of broader European ideas about masculinity. While the younger, passive sexual partners are 'made victims' and thus feminised, there is no suggestion that the sexual aggressors have lost their masculine dominance. Missionaries apparently made no attempt to discover whether Aboriginal people viewed sexual roles in this way or not. Furthermore, there is no evidence of the men allegedly involved in sodomy being singled out by missionaries as a separate problematic group. Rather, their behaviour was considered simply more evidence of the general Aboriginal need for Christian conversion. Thus, the proposed solution was religion and respectable marriage, to be guaranteed through missionary or protectorate supervision. The suggestion by a government doctor that young men could be straightened out through military service was dismissed 
by Robinson, on the grounds that a military environment would only encourage 'the disgusting practice'. Protector Parker added testily that he believed the word of God was stronger than 'the drill sergeant's cane'. ${ }^{17}$ Overall, however, there is little evidence of concrete steps being taken to police relationships between men. This indicates not only the limitations of missionary power, at a time when pre-colonial forms of authority and ceremonial life remained powerful and when Aboriginal people were not being physically forced onto missions, but also the fact that same-sex encounters, while considered savage and sinful, were not the greatest sexual issue to attract missionary concern.

Another issue, which attracted only a small amount of missionary concern, was the idea that Aboriginal men posed a sexual threat to white women. Stories of sex between white women and black men are notorious for exciting horror and violence in European colonies, as well as providing a pretext for curtailing colonised people's rights. However, in Australia during the early nineteenth century, the issue arises in missionary accounts only a handful of times. In a letter to his missionary society colleagues in 1832, JCS Handt of the Wellington Valley mission related two such stories. There was a tale circulating in the colony, he said, of a white woman shipwrecked near Moreton Bay and held prisoner by Aborigines; the woman, Handt believed, had several 'Mulatto' children. ${ }^{18}$ This rumour reminded him of his own recent experience in Sydney, when an apparently white woman with a child on her arm had approached him during the annual Parramatta native feast and asked him for bread. Handt was astonished to hear that she 'belonged to the blacks'. The first women he depicted as a suffering victim, the second, he assumed, must have 'abandoned herself to such a wretched life and company' ${ }^{19}$ This seemed credible to Handt, who considered most colonial white women immoral. ${ }^{20}$

Meanwhile, Rev Lancelot Threlkeld of the Lake Macquarie mission near Newcastle described an Aboriginal man educated at the Male Orphan School in Sydney, who eloped with a settler's daughter. The story could have been used to invoke the supposed sexual threat of Aboriginal men and the dangers of trying to integrate 'savages' into European society, but this was not how Threlkeld portrayed it. Rather, he stated that the man was intelligent and very handsome and that the couple eventually settled as respectable farmers. ${ }^{21}$ Elsewhere, Threlkeld expressed concern that the Native Police might attack white and black women, but merely concluded that they needed to be taught military self-discipline. $^{22}$ These examples are too isolated to be conclusive, but they do not convey a strong, general sense of racial or sexual paranoia, and variables like the behaviour, class and level of 'civilisation' of the men and women involved seem to have strongly influenced missionaries' final conclusions. This is suggestive of a climate where racial and sexual views were in something of a state of flux, and where local variations could be significant. Perhaps the very 
isolation of these accounts is the most important element here; the issue of sex between Aboriginal men and European women simply does not seem to have concerned missionaries or protectors very much at all.

It might be assumed that they avoided the topic for fear of inciting racial violence, but such sexual stories do not seem to have featured prominently in many government or settler accounts either. There were, of course, exceptions to this, perhaps most notably the story of Eliza Fraser's shipwreck in south-eastern Queensland, which emerged in the late 1830s, and the frontier legends about the 'White Woman of Gippsland', which were first told in the 1840s. The Fraser captivity narratives - whose racial, sexual and class politics have been discussed by Kay Schaffer - did not feature in missionary or protectorate accounts at this time. Indeed, Schaffer's work suggests that during the 1830s the story attracted more interest in Britain and the United States than in Australia, being linked to British class and political turmoil and America's negotiation of its own frontier history through stories of white people captured by 'natives'. ${ }^{23}$ During this period, the White Woman of Gippsland stories seem to have had greater local resonance. These stories told of a woman stranded by a shipwreck, held prisoner by the Kurnai and forced to marry an elder, Bungelene. These rumours, not coincidentally, circulated at the same time as the violent dispossession of the Kurnai people. Missionaries, incidentally, did not discuss this story, and protectors dismissed it as unlikely and an excuse for colonial violence. ${ }^{24}$

This is one of the few stories involving sex between Aboriginal men and white women during this era to have received much attention from historians, but even here, gaps in the historiography of Australian racism are evident. It is only recently that Julie Carr has discussed in depth how this legend reflected changes in colonial society and politics. (Interestingly, Carr also notes that stories about sex between European women and Indigenous men were, overall, rare in Australia, particularly compared to North America. $)^{25}$ Apart from Carr's work, other historians who have narrated the story, like Michael Cannon, have tended not to examine its sexual and racial significance in depth. Even Kate Darian-Smith, who discusses the importance of the figure of the frontier white woman to Australian national identity, still tends to link events from the 1840s unproblematically with racism from later decades. ${ }^{26}$ Meanwhile, Schaffer's work on Eliza Fraser arguably focuses more on situating the 1830s versions of Fraser's story within British imperial literature than within Australian representations of Aboriginality. ${ }^{27}$ Thus, greater discussion is still needed on how sexualised racism has evolved in colonial Australia.

It is interesting to speculate on why colonists appeared to pay a relative lack of attention to sex between Aboriginal men and European women in the early nineteenth century. The small number of European women in rural districts at this time was no doubt relevant. However, the fact that sexualised nationalist 
ideology had not yet strongly emerged in the Australian colonies was also significant. The image of the white woman as a force of purity and morality on the frontier and a symbol of racial and sexual vulnerability for white men to protect would become vital during the late nineteenth and early twentieth centuries, feeding into a number of developments like the rise of Australian nationalism, concerns about the white birth rate, and the emergence of disciplines of racial and sexual science. ${ }^{28}$ However, during the 1830 s and 1840 s, it seems to have been less of a general concern.

Another reason for this may well have been a general colonial downplaying of Aboriginal men's sexual vitality. Some portrayals of Aboriginal men disregarding chastity and monogamy and brutally seizing as many wives as they wanted were put forward by explorers, including David Collins and Edward John Eyre, and settlers and journalists like George Arden, Edward M Curr and George Hamilton. ${ }^{29}$ While these accounts may have referred to real events, the way these were portrayed was almost certainly shaped by the pre-existing idea that sexual brutality was normal behaviour for 'savages', and by the continuing desire to rationalise Aboriginal dispossession.

However, what is more surprising is that in the early nineteenth century such descriptions of Aboriginal men as brutally lustful seem to have been, overall, quite rare. Few settlers or explorers portrayed lust as Aboriginal people's defining quality - instead, they emphasised traits like laziness, cruelty or treachery. (Some examples of this attitude are evident in the works of David Collins, Charles Sturt, John Henderson, Francis Barrallier, RJ Massie and James Malcolm.) $)^{30}$ Furthermore, even sexualised colonial accounts still tended to place greater stress on stories of men beating their wives or lazily depending on women's work. For example, Eyre, Arden and Peter Cunningham, whose descriptions of Aborigines were quite sexual in some ways, still explained Aboriginal polygamy in economic terms, describing Aboriginal women as servants (rather than concubines), valued mainly for their hard labour. ${ }^{31}$ Pre-existing European ideas of black men as virile and sexually deviant, while popular in other parts of the world, appear to have generally been secondary in Australian colonial accounts, when mentioned at all.

The fact that few early colonial accounts defined Aboriginal men in terms of savage lust is, I would suggest, no accident. During this period, the new sciences of anatomy, biology, physiology and palaeontology were becoming sophisticated, popular and entangled in world politics, and human development was being increasingly viewed as naturally hierarchical and progressive. The extermination of so-called weaker races was often depicted as a natural, positive part of this process. For Europeans unsettled by rapid industrialisation and social change and seeking to rationalise their own growing imperial dominance, such ideas could be strongly appealing. ${ }^{32}$ While many colonial sources attributed 
indigenous depopulation to changeable material causes, the notion that this demise was inevitable and necessary was growing in North America, New Zealand and, increasingly, Australia. ${ }^{33}$ Herman Merivale, lecturing at Oxford in the 1840 s, noted the increasing popularity of the claim that Aboriginal improvement was hopeless - 'the feebler race must yield to the stronger; the white is destined to extirpate the savage ... the mere contact of Europeans is fatal to him [the Aborigine] in some unknown manner' ${ }^{34}$ Perhaps the fullest scientific expression of these ideas in an Australian context came from naturalist PE de Strzelecki, who in 1845 asserted that indigenous demise occurred worldwide as the result of a mysterious process by which indigenous women, through sex with white men, became unable to have children by indigenous men. ${ }^{35}$

Colonists were not necessarily being self-conscious and cynical when they constructed or embraced stereotypes of Aborigines as sterile and doomed; such ideas were in keeping with international trends in Western thought. However, there is no doubt that such stereotypes could be appealing and useful in the Australian colonies. The figure of the virile, promiscuous black man whose sexuality must be regulated by a white master - important to the rationalisation of American slavery — was less attractive in Australia, where colonialism did not rely on the breeding and exploitation of Indigenous people so much as on their supposedly inevitable deaths. In a colonial setting where the legal, physical and cultural absence of Aboriginal people from the land became crucial to national development and white Australian identity, and where Aborigines were repeatedly described as a dying race, a portrayal of Aboriginal men as oversexed, lustful and reproductive would not necessarily have appealed to colonists. Nor would it have fit in with growing international beliefs in indigenous peoples in settler colonies as 'doomed races'. (As an interesting comparison, Robert Wokler points out that some eighteenth-century commentators, including Thomas Malthus, attributed the decline in the indigenous American population to lack of male virility.) ${ }^{36}$

Protectors and missionaries during the early nineteenth century rarely depicted Aborigines as inevitably doomed and sterile, although the question of how they may have been privately or subconsciously influenced by such arguments would make an interesting topic for further discussion. However, like other colonists, they seemed less interested in Aboriginal men's lusts than in some of their other activities, particularly the lending or prostitution of Aboriginal women to European men. The bestowing of women began as a traditional method of forging family and economic alliances between different Aboriginal groups. In a colonial context, it was sometimes an initial response to European presence, an attempt to incorporate Europeans into Indigenous social systems. ${ }^{37}$ Later, however, as Aboriginal poverty worsened, sex became more directly related to immediate needs for food and supplies. This 'prostitution', as missionaries defined it, 
troubled humanitarians for several reasons. Not only was prostitution considered sinful in principle, but its connection to the spread of venereal disease, the dangerously low Aboriginal birth rate and violent clashes between European and Aboriginal men led many missionaries to cite prostitution as a major cause of imminent Aboriginal 'extinction'. ${ }^{38}$

I would also argue that missionaries linked Aboriginal men's involvement in prostitution to broader concerns about hard work and property ownership. As Elizabeth Fee has explored, imperial discourse frequently linked the supposed sexual looseness of 'savages' with lack of property sense. Many nineteenth-century historians, anthropologists and philosophers asserted that in 'savage' societies women and children belonged to the horde and that the emergence of patrilineal descent systems, monogamous marriage and the nuclear family were key signs of progress. The development of bourgeois forms of male authority over women and children was linked to the growth of private property and liberalism and the reduction of women's public labour. ${ }^{39}$ Thus, accusations of indigenous promiscuity could serve not only to depict colonised peoples as primitive, but also to reinforce claims that they lacked property sense, which in turn helped to rationalise the theft of their land and resources. ${ }^{40}$

While missionaries did not necessarily wish to justify this theft, they did wish to transform Aboriginal people's ideas about labour and property, and some of these concerns were sexualised. Unlike some colonists, though, missionaries did not equate alleged Aboriginal promiscuity with total indifference to property. They often claimed that Aboriginal men treated their wives as servants, insisting on women's economic and sexual work to support their families. Missionary William Watson of Wellington Valley, for example, saw Aboriginal women as slaves, coerced into manual and sexual labour. He claimed that every European in the neighbourhood had at least one woman living with him — some, Watson said, kept several girls as young as eight — with the cooperation of their male relatives, who were being bribed. ${ }^{41}$ Meanwhile, Methodist Joseph Orton claimed the men treated their wives like horses and bullocks, and protector James Dredge claimed that Aboriginal women were forced into prostitution - 'were they to refuse to yield to the directions of their savage lords ... they would ensure an unmerciful beating, if not be killed on the spot' ${ }^{42}$ Thus, to missionaries, prostitution did not demonstrate that Aboriginal men lacked a sense of their wives as sexual property. Rather, missionaries implied, by renting their wives to other men instead of controlling them monogamously, Aboriginal husbands showed a lack of Christian chastity, but also assumed an economic role that seemed parasitical, receiving what Rev James Günther of Wellington Valley called 'the wages of $\sin ^{\prime} .43$ The claim that Aboriginal men refused to earn their keep honestly was in keeping with missionaries' and protectors' frequent general complaints about Aboriginal 'vagrant habits', 'remarkable aversion to labour', 
'indolence', 'fecklessness' and 'erratic', 'fickle' behaviour. ${ }^{44}$ Thus, Handt, when lecturing Aboriginal men on the sin of prostitution, emphasised that their 'idleness' was the main cause behind this, and one report from the Wellington Valley mission claimed that prostituted Aboriginal women were 'the unwilling victims of their husbands' indolence' ${ }^{45}$

The project of reshaping Aboriginal men's sexuality would, missionaries hoped, involve conveying a different version of masculine control. This European masculine ideal entailed firm control over one's own sexual urges and strict but benevolent control over one's legal monogamous sexual partners. In the mission context, however, this was problematic, as Aboriginal men, often described as lazy and undisciplined (and thus, in some respects, childlike), could not necessarily be trusted with such control. Through dependence on and obedience to the missionaries, Aboriginal men would supposedly learn correct masculine behaviour, but at the same time this dependence and obedience reinforced their low status. For example, Watson claimed proudly that men who read the Bible became possessive of their wives and left them on the mission away from predatory Europeans. ${ }^{46}$ Here, Aboriginal men were demonstrating the monogamy and possessiveness missionaries had hoped to impart. But they were expected to do this by submitting themselves and their wives to missionary sexual supervision. Presumably, missionaries envisaged Aboriginal men eventually moving beyond this immature sexual stage, but this future prospect was rarely discussed.

Attempts to alter and control Aboriginal sexuality involved different types of physical restriction and emotional manipulation. These often varied according to gender. The physical power of missionaries and protectors at this time was not great; Aboriginal people in many districts were still able to survive off missions, and missionaries' and protectors' relationships to government and police were often troubled and uncooperative. ${ }^{47}$ However, force was sometimes used to restrain the sex lives of women and girls. This included locking girls in the mission overnight, using police to remove women from 'debauched' living arrangements with European men, and, occasionally at Wellington Valley, beating young girls for sexual behaviour. ${ }^{48}$ Attempts to change Aboriginal men's sexual behaviour, in contrast, hardly ever involved direct physical force.

Missionaries' main tactic for teaching their sexual values to Aboriginal men was through conversation and lecturing, through which they hoped to induce feelings of morality and shame. The way missionaries saw their role was not unlike that of strict Protestant parents of the period, trying to impart self-control to their children. Through frequent lecturing and daily Christian routine, the child or, in this case, the native - would internalise a sense of guilt and of being watched at all times by a stern God. ${ }^{49}$ Thus, when reproving Aboriginal men for sexual sin, missionaries reminded them that monogamous marriage had been 
set down by God, that God was always watching and judging them, and that illicit sex was proof that they did not yet have a 'new heart' and would not be saved. ${ }^{50}$

Missionaries and protectors also tried to cultivate an image of themselves as powerful moral observers hurt by evidence of sin. For instance, one night at Wellington Valley the missionaries were woken by whispering in the girls' bedroom, and rushed in in time to see two young men vanishing up the chimney. Upon catching one of the guilty youths, Goongeen, Mr and Mrs Watson reproved him - 'you know Goongeen that it is very wrong, you have been told so very many times, and your conduct makes us very sorry, it makes us that we cannot eat or drink or sleep'. Goongeen, who had a close, if vexed, relationship with the missionaries, knew enough to at least give the impression of repentance. ${ }^{51}$ Thus, emotional connections and observation by God were used to try to cultivate a guilty conscience.

Aboriginal men's responses to these moral campaigns varied but tended to demonstrate the limitations of missionary power. Attempts to incorporate missionaries into sexual relationships for money or supplies were very rare, presumably owing to their obvious disgust at such relationships and their general willingness to provide supplies in return for church attendance and farm work. I have found only one example of an Aboriginal man trying to forge a serious marital link with a missionary or protector. When protector Charles Sievwright was travelling around Keilambete, he visited the camp of Burguidenang, a man from the Terang region, whom he had helped to release from prison. Burguidenang embraced Sievwright closely, welcomed him as an honoured guest, and, accompanied by the elders, offered his infant daughter in betrothal to Sievwright's 11-year-old son. Sievwright delicately refused but was touched by the gesture. ${ }^{52}$ This story seems to have been unique, however, prompted by an unusually strong bond between the two men.

On other occasions, Aboriginal men used protectors to help remove their wives from sexual relationships with other men. Protector Sievwright, for example, was asked in 1839 by a group of Barrabool (Wathaurung) men to help retrieve three women being forcibly held in a convict servant's hut. The men threatened that if Sievwright was unsuccessful they would set fire to the hut and spear the white men. Sievwright removed the women and had the guilty servants flogged. ${ }^{53}$ In the same year, at protector William Thomas's camp near Melbourne, an Aboriginal man confidently demanded Thomas's help in looking for his missing wife, insisting that Thomas search the house of a neighbouring European and the miams of visiting Aborigines, and threatening to report Thomas to the police if he did not cooperate. ${ }^{54}$ These men may have been taking advantage of the protectors' opposition to illegitimate sex, but the confidence with which 
they acted indicates that they also believed they had the right to expect help, as they had been told the protectors were there to represent their interests.

However, many Aboriginal men's responses to missionary sexual agendas were less cooperative. Many continued to have relationships with girls and women on the missions and tolerate or encourage their wives' prostitution, and others ignored, mocked or challenged missionaries' lectures on sexual propriety. Some men questioned missionaries' opposition to prostitution, wanting to know why other Europeans found it acceptable and why missionaries did not lecture them. At Wellington Valley in 1833, Watson lectured a man called Woowah on the Christian necessity of having one wife only and not lending her to others. Woowah responded 'white fellow all about make a light God, Black fellow all about very stupid. What for white fellow always say you lend me yeener [woman] belonging to you ... then I give you bread, I give you milk, shirt etc?' ${ }^{55}$ The missionary could not adequately respond to this. When one man at Wellington Valley responded to James Günther's lectures against promiscuity by asking 'Why don't you talk that way to White fellas?' Günther acknowledged 'It is melancholy but the Black has some sight and must be in some respect justified for passing a remark like that' ${ }^{56}$ Handt reproved another man for prostituting his wife, and the man replied 'that white men should know that it was wrong, and not have asked her of him as they know about God'. To this, Handt responded 'A just reply indeed. ${ }^{57}$

More serious disputes arose when Aboriginal men saw missionaries as exercising too much control over the women. Protector Thomas, for example, caused considerable turmoil by interfering in the betrothal of a Kulin woman, Kitty, whose uncle had removed her from her husband to marry her to someone else. Thomas was far more concerned about the sanctity of marriage than about Kitty's wishes; he dragged her forcibly away from her female relatives and threatened her with prison if she left her husband again. Thomas's actions disturbed Kitty's husband, Benbow, who begged him not to interfere, and angered her uncle, Ningollobin, who protested 'before white man came Black fellows did as they like with Lubras what for now sulky no good that' ${ }^{58}$ It should be noted, though, that the most direct coercion Thomas used was against the woman herself, and that the issue was only resolved through compromise with traditional practices; Benbow took Kitty back but had to give one of his female relatives to Ningollobin. Thus, the protector's authority was evident but also limited. ${ }^{59}$

Disputes with Aboriginal men over women were particularly evident at Wellington Valley, where the local police magistrate claimed that Aboriginal men had asked him to forcibly remove the women from missionary custody. ${ }^{60}$ One Wiradjuri man, Frederick, was furious when missionaries refused to let him marry a mission girl despite his attempts to negotiate by promising to build a house at the mission and leave his wife there most of the time. Upon being 
rejected, Frederick threatened to borrow muskets from local Europeans and remove all the girls by force. To this, Watson could only respond with warnings of spiritual, rather than physical, punishment, saying 'Well Frederick ... you have not yet got a new heart, you are not a Christian. ${ }^{\prime 1}$ Other men accused the missionaries of keeping the women for sex. One man, Kabbarin, told Watson 'you like yinars [women] too much ... what do you want with Black yinars? ... Why don't you go to Sydney? plenty white yinars sit down there. Yes yes you get plenty of children by and by.' Watson was furious, especially when the other people listening laughed at him. ${ }^{62}$ These accusations and threats may not have been sincere, but the men's resentment at missionary interference in betrothals was strongly felt, and was one of the many reasons why the first missions were unsuccessful.

Attempts by the first missionaries and protectors to reshape Aboriginal sexuality by arranging respectable Christian marriages is a topic where much research has yet to be done. At present, it seems that perhaps the most significant point here is the general absence of such marital plans in the south-east in the early nineteenth century. The poverty, prostitution and violence of the frontier and the general lack of committed Aboriginal Christians may have made missionaries and protectors too pessimistic to plan marriages. Some also noted that few Europeans would consider marrying Aborigines, and few Aborigines were considered sufficiently Christianised to marry decently amongst themselves. ${ }^{63}$ Some missionary attempts to plan marriages also met with considerable Aboriginal resistance when they interfered with pre-existing betrothals or linked young people forbidden to each other under traditional law. ${ }^{64}$ This would make a significant topic for further investigation.

The first protectors and missions operated at a time when colonial understandings of Aboriginal sexuality were influenced by stereotypes of savages as lazy, uncontrolled and amoral, as well as by a particular feature of settler colonialism: the attraction of portraying Indigenous people as doomed and sterile, rather than as lustful, uncontrolled breeders. This intellectual climate seems to have influenced to some extent missionary attitudes towards Aboriginal men's sexuality. However, their attitudes were also shaped by particular concerns about the relationships between sex and heathen sin, imported vices, hard labour and property ownership. A study of missionaries' and protectors' attempts to instil self-discipline and shame in Aboriginal men, and the men's varied responses to this - including cooperation, opportunism and aggressive resistance - helps to illuminate a mission both sympathetic and chauvinistic in its intentions and limited in its power. 
Transgressions

\section{References}

\section{Primary sources}

Aboriginal Affairs Records, (AAR), VPRS4467, Victorian Public Records Office.

Dredge, James, Diaries, Notebooks and Letterbook: ?1817-1845, (JDD), MS11625, State Library of Victoria.

Thomas, William, Journal and Papers, 1834-1844, (WTP), MF323, Australian Institute of Aboriginal and Torres Strait Islander Studies.

Tuckfield, Francis, Journal: 1837-1842, MS11341, Box 655, State Library of Victoria.

Wellington Valley Project, (WVP): Letters and Journals relating to the Church Missionary Society Mission to Wellington Valley, New South Wales, 1830-45, a critical electronic edition, Hilary M Carey and David A Roberts (eds), University of Newcastle, <http://www.newcastle.edu.au/centre/wvp/>

Wesleyan Methodist Missionary Society Archive, Australasia 1812-1889, (WMMS), Boxes 1 and 2, Mp2107, National Library of Australia.

\section{Secondary sources}

Adams, David Wallace 1995, Education for Extinction: American Indians and the Boarding School Experience, 1875-1928, University of Kansas Press, Lawrence.

Aldrich, Robert 2003, Colonialism and Homosexuality, Routledge, London and New York.

Arden, George 1843, 'Civilization of the Aborigines', in Arden's Sydney Magazine of Politics and General Literature, vol. 1, no. 1, September: 65-82.

Arkley, Lindsey 2000, The Hated Protector: The Story of Charles Wighton Sievwright, Protector of Aborigines, 1839-42, Orbit Press, Mentone.

Barrallier, Francis 1975, Journal of the Expedition into the Interior of New South Wales, 1802, Marsh Walsh, Melbourne.

Barthelemy, Anthony Gerard 1987, Black Face, Maligned Race: The Representation of Blacks in English Drama, from Shakespeare to Southerne, Louisiana State University Press, Baton Rouge and London.

Bowler, Peter J 1984, Evolution: The History of an Idea, University of California Press, Berkeley.

1989, The Invention of Progress: The Victorians and the Past, Basil Blackwell, Oxford. 
Brantlinger, Patrick 2003, Dark Vanishings: Discourse on the Extinction of Primitive Races, 1800-1930, Cornell University Press, Ithaca and London.

Bridges, Barry John 1970, 'James Dredge in Australia', Descent 5(1): 1-16.

— 1978, 'The Church of England and the Aborigines of New South Wales, 1788-1855', PhD thesis in History, University of New South Wales, Sydney.

Campbell, Alastair H 1987, John Batman and the Aborigines, Kibble Books, Malmsbury.

Cannon, Michael (ed.) 1982, Historical Records of Victoria: The Aborigines of Port Phillip, 1835-1839, vol. 2A, Victorian Government Printing Office, Melbourne.

1983, Historical Records of Victoria: Aborigines and Protectors, 1838-1839, vol. 2B, Victorian Government Printing Office, Melbourne.

1990, Who Killed the Koories? William Heinemann, Port Melbourne.

Carr, Julie E 200la, "“Cabin'd, Cribb'd and Confin'd": the White Woman of Gipps Land and Bungalene', in Barbara Creed and Jeanette Hoorn (eds), Body Trade: Captivity, Cannibalism and Colonialism in the Pacific, Routledge, New York: 167-179.

2001b, The Captive White Woman of Gipps Land: In Pursuit of a Legend, Melbourne University Press, Carlton South.

Christie, Michael 1979, Aborigines in Colonial Victoria, 1835-86, University of Sydney Press, Sydney.

Cohen, William B 1980, The French Encounter with Africans: White Responses to Blacks, 1530-1880, Indiana University Press, Bloomington and London.

Collins, David 1798, An Account of the English Colony in New South Wales, With Remarks on the Dispositions, Customs, Manners, etc, of the Native Inhabitants of that Country, vol. 1, Reed/Royal Australian Historical Society, Sydney.

Corris, Peter 1968, Aborigines and Europeans in Western Victoria, Australian Institute of Aboriginal Studies, Canberra.

Critchett, Jan 1990, A 'Distant Field of Murder': Western District Frontiers 18341848, Melbourne University Press, Burwood.

Cunningham, Peter 1827, Two Years in New South Wales, vol. 2, Henry Colburn, London.

Cunningham, Hugh 1995, Children and Childhood in Western Society Since 1500, Longman, London. 
Curr, Edward M 1883, Recollections of Squatting in Victoria, then called the Port Phillip District (from 1841-1851), Melbourne University Press, Carlton.

Darian-Smith, Kate 2001, 'Material Culture and the "Signs" of Captive White Women', in Barbara Creed and Jeanette Hoorn (eds), Body Trade: Captivity, Cannibalism and Colonialism in the Pacific, Routledge, New York: 180-192.

Dredge, James 1845, Brief Notes on the Aborigines of New South Wales, James Harrison, Geelong.

1983, 'Journal', in Michael Cannon (ed.), Historical Records of Victoria: Aborigines and Protectors, 1838-1839, vol. 2B, Victorian Government Printing Press, Melbourne.

Evans, Raymond 1999, Fighting Words: Writing About Race, University of Queensland Press, St Lucia.

Eyre, Edward John 1845, Journals of Expedition of Discovery into Central Australia and Overland from Adelaide to King George's Sound in the years 1840-1, vol. 2, T and W Boone, London.

Fee, Elizabeth 1974, 'The Sexual Politics of Victorian Social Anthropology', in Mary S Hartman and Lois Banner (eds), Clio's Consciousness Raised: New Perspectives on the History of Women, Harper Torchbooks, New York: 86-103.

Fels, Marie Hansen 1988, Good Men and True: The Aboriginal Police of the Port Phillip District, 1837-1853, Melbourne University Press, Burwood.

Frauenfelder, Peter (ed.) 1997, Aboriginal Communities: the Colonial Experience, Port Phillip District, Education Centre of the State Library of Victoria, Melbourne.

Gilman, Sander L 1985, Difference and Pathology: Stereotypes of Sexuality, Race, and Madness, Cornell University Press, Ithaca.

Gipps, Sir George, to Lord John Russell, 7 May 1840, in Historical Records of Australia, series 1, vol. XX, February 1839 - September 1840, Library Committee of the Commonwealth Parliament, Sydney, 1924: 607-647.

Goodall, Heather 1996, Invasion to Embassy: Land in Aboriginal Politics in New South Wales, 1770-1972, Allen \& Unwin, St Leonards.

Greven, Phillip 1977, The Protestant Temperament: Patterns of Child-Rearing, Religious Experience and the Self in Early America, Alfred A. Knopf, New York.

Grimshaw, Patricia 1994, Colonialism, Gender and Representations of Race: Issues in writing women's history in Australia and the Pacific, University of Melbourne History Department, Parkville. 
Haebich, Anna 2000, Broken Circles: Fragmenting Indigenous Families, 1800-2000, Fremantle Arts Centre Press, Fremantle.

Hamilton, George 1879, Experiences of a Colonist Forty Years Ago, and a Journey from Port Phillip to South Australia in 1839, Frearson \& Brother, Adelaide.

Henderson, John 1832, Observations on the Colonies of New South Wales and Van Diemen's Land, Baptist Mission Press, Calcutta.

Henningham, Nikki 2000, “"Hats off, Gentlemen, to our Australian Mothers!”: Representations of White Femininity in North Queensland in the Early Twentieth Century', in Martin Crotty, John Germov and Grant Rodwell (eds), 'A Race for a Place': Eugenics, Darwinism and Social Thought and Practice in Australia, University of Newcastle, Callaghan: 156-166.

Huhndorf, Shari H 2001, Going Native: Indians in the American Cultural Imagination, Cornell University Press, Ithaca and London.

Hunt, Susan 1986, Spinifex and Hessian: Women in North-West Australia, 18601900, University of Western Australia Press, Perth.

Jebb, Mary Anne and Haebich, Anna 1992, 'Across the Great Divide: Gender Relations on Australian Frontiers', in Kay Saunders and Raymond Evans (eds), Gender Relations in Australia: Domination and Negotiation, Harcourt Brace Jovanovich, Sydney: 20-41.

Johnston, Colin and Johnston, Robert 1988, 'The Making of Homosexual Men', in Verity Burgmann and Jenny Lee (eds), Staining the Wattle: A People's History of Australia since 1788, Penguin, Ringwood: 87-99.

Langhorne, George, to Colonial Secretary, 31 December 1837, in Michael Cannon (ed.), Historical Records of Victoria: The Aborigines of Port Phillip, 18351839, vol. 2A, Victorian Government Printing Press, Melbourne, 1982: 208-209.

to CJ LaTrobe, 15 October 1839, in Michael Cannon (ed.), Historical Records of Victoria: Aborigines and Protectors, 1838-1839, vol. 2B, Victorian Government Printing Press, Melbourne, 1983: 507-510.

de Lepervanche, Marie 1989, 'Breeders for Australia: A National Identity for Women', Australian Journal of Social Issues 24(3), August: 163-180.

Malcolm, James 1997, Evidence, 'Report from the Select Committee on the Condition of the Aborigines, 1845', in Peter Frauenfelder (ed.), Aboriginal Communities: the Colonial Experience, Port Phillip District, Education Centre of the State Library of Victoria, Melbourne: 55-63.

Malthus, Thomas 1986, 'An Essay on the Principle of Population', in EA Wrigley and David Souden (eds), The works of Thomas Robert Malthus, vol. 1, William Pickering, London. 
Markus, Andrew 1990, Governing Savages, Allen \& Unwin, Sydney.

Massie, RJ, to Colonial Secretary, 31 December 1847, in Historical Records of Australia, series 1, vol. XXVI, October 1847 - October 1848, Library Committee of the Commonwealth Parliament, Sydney: 393-394.

McGrath, Ann 1990, 'The White Man's Looking-Glass: Aboriginal-Colonial Gender Relations at Port Jackson', Australian Historical Studies 24(95), October: 186-206.

McGregor, Russell 1997, Imagined Destinies: Aboriginal Australians and the Doomed Race Theory, 1880-1939, Melbourne University Press, Carlton South.

Merivale, Herman 1861, Lectures on Colonization and Colonies, first delivered 1839-1841, London, Oxford University Press.

Miner, Earl 1972, 'The Wild Man Through the Looking Glass', in Edward Dudley and Maximillian E. Novak (eds), The Wild Man Within: An Image in Western Thought from the Renaissance to Romanticism, University of Pittsburgh Press, London: 87-114.

O'Brien, Patty 1998, "The Gaze of the "Ghosts": Images of Aboriginal Women in New South Wales and Port Phillip (1800-1850)', in Jan Kociumbas (ed.), Maps, Dreams, History: Race and Representation in Australia, Department of History, University of Sydney, Sydney: 313-400.

Pettman, Jan 1992, Living in the Margins: Racism, Sexism and Feminism in Australia, Allen and Unwin, North Sydney.

Rae-Ellis, Vivienne 1988, Black Robinson, Protector of the Aborigines, Melbourne University Press, Collingwood.

Reece, Robert 1974, Aborigines and Colonists: Aborigines and Colonial Society in New South Wales in the 1830s and 1840s, Sydney University Press, Sydney.

Robertson, Priscilla 1988, 'Home As A Nest: Middle Class Childhood in Nineteenth Century England', in Lloyd deMause (ed.), The History of Childhood: The Untold Story of Child Abuse, Peter Bedrick Books, New York: 407-431.

Robinson, George Augustus 1998a, Journals: Port Phillip Aboriginal Protectorate, Ian D Clark (ed.), vol. 1, 1 January 1839 - 30 September 1840, Heritage Matters, Melbourne.

— 1998b, Journals: Port Phillip Aboriginal Protectorate, Ian D Clark (ed.), vol. 4, 1 January 1844 - 24 October 1845, Heritage Matters, Melbourne.

— 1997, Evidence, 'Report from the Select Committee on the Condition of the Aborigines, 1845', in Peter Frauenfelder (ed.), Aboriginal Communities: 
the Colonial Experience, Port Phillip District, Education Centre of the State Library of Victoria, Melbourne: 51-54.

2001, '1848 Annual Report', in Ian D Clark (ed.), The Papers of George Augustus Robinson, Chief Protector, Port Phillip Aboriginal Protectorate, vol. 4, Clarendon, Heritage Matters: 139-156.

Russell, Penny 1994, A Wish of Distinction: Colonial Gentility and Femininity, Melbourne University Press, Carlton.

Russett, Cynthia Eagle 1989, Sexual Science: The Victorian Construction of Womanhood, Harvard University Press, Cambridge, Massachusetts.

Schaffer, Kay 1995, In the Wake of First Contact: The Eliza Fraser Stories, Cambridge University Press, Cambridge.

Schiebinger, Londa 1993, Nature's Body: Gender in the Making of Modern Science, Beacon Press, London.

Sievwright, Charles 1994, 'Report: September 1839 - May 1840', in Mira Lakic and Rosemary Wrench (eds), Through Their Eyes: An Historical Record of Aboriginal People in Victoria as Documented by the Officials of the Port Phillip Protectorate, 1839-1841, Museum of Victoria, Melbourne: 115127.

Sommerville, C John 1982, The Rise and Fall of Childhood, Sage Publications, Beverly Hills.

Stepan, Nancy 1982, The Idea of Race in Science: Great Britain, 1800-1960, MacMillan Press, London.

Strzelecki, PE de 1845, Physical Descriptions of New South Wales and Van Diemen's Land, Longman, London.

Sturt, Charles 1833, Two Expeditions into the Interior of Southern Australia, Smith, Elder \& Co., London.

1861, First Report of the Central Board Appointed to Watch over the Interests of the Aborigines in the Colony of Victoria, Melbourne, Government Printer, GMF105, Box 2, State Library of Victoria.

Threlkeld, LE 1974, 'Correspondence and Early Reports relating to the Aboriginal Mission, 1825-1841', in Niel Gunson (ed.), Australian Reminiscences and Papers of L. E. Threlkeld, Missionary to the Aborigines, 1824-1859, vol. 2, Australian Institute of Aboriginal Studies, Canberra: 177-306.

Tyrell, Alex, 1993, A Sphere of Benevolence: The Life of Joseph Orton, Wesleyan Methodist Missionary (1795-1842), State Library of Victoria, Melbourne.

Walker, David, 1999, Anxious Nation: Australia and the Rise of Asia, 1850-1939, University of Queensland Press, St Lucia. 
White, Richard 1981, Inventing Australia: Images and Identity, 1688-1980, Allen and Unwin, Sydney.

Wokler, Robert 1995, 'Anthropology and Conjectural History in the Enlightenment', in Christopher Fox, Roy Porter and Robert Wokler (eds), Inventing Human Science: Eighteenth Century Domains, University of California Press, Berkeley: 31-52.

\section{ENDNOTES}

1 Francis Tuckfield, Journal: 1837-1842, 11 May 1841, MS11341, Box 655, State Library of Victoria; Francis Tuckfield to General Secretaries, 30 October 1841, Wesleyan Methodist Missionary Society Archive, Australasia 1812-1889 (WMMS), Box 2, 'Correspondence, Australia, 1840-1852', Mp2107, National Library of Australia.

2 For example, Cannon 1983: 366; Cannon 1990: 132; Christie 1979: 90-94, 101-05; Corris 1968: 73-79, 93-94; Haebich 2000: 348-51; O’Brien 1998: 383-85, 395.

${ }^{3}$ For example, Bridges 1970, 1978; Cannon 1990; Christie 1979; Corris 1968; Rae-Ellis 1988; Reece 1974.

4 Grimshaw 1994; Hunt 1986; Jebb and Haebich 1992; McGrath 1990; O’Brien 1998.

5 Evans 1999: 136-37, 156-58; Jebb and Haebich 1992: 34; O'Brien 1998: 321-23; Pettman 1992: $26-28$.

6 Barthelemy 1987: 5; Cohen 1980: 20; Miner 1972: 89, 95.

7 Barthelemy 1987: 6-12, 120; Cohen 1980: 13-19.

8 Dredge 1845: 11.

9 Lydia Günther to William Jowett, 12 January 1839: 2-3, Wellington Valley Project (WVP); William Watson, Journal, 8 May 1835: 6, WVP.

10 Cannon 1990: 135.

11 JCS Handt, Journal, 17 February 1835: 10, WVP.

12 Edward Stone Parker, 14 July, 'Quarterly Journal', 1 June - 31 August 1842, Aboriginal Affairs Records (AAR), VPRS4467, Reel 2, Victorian Public Records Office.

13 Bridges 1978: 810.

14 Robinson 1998a: 285.

15 Cannon 1990: 135-36.

16 Aldrich 2003: 219-224; Johnston and Johnston 1988: 87.

17 Cannon 1990: 136.

18 JCS Handt to T Woodrooffe and Dandeson Coates, 23 April 1832: 1, WVP.

19 JCS Handt to T Woodrooffe and Dandeson Coates, 23 April 1832: 1, WVP.

20 Bridges 1978: 307-08.

21 Threlkeld 1974, vol. 2: 300.

22 Threlkeld 1974, vol. 2: 264

23 Schaffer 1995: 29-96.

24 Robinson 2001: 143; Thomas, Journal and Papers, 1834-1844 (WTP), 7 October 1846, 29 January 1847, 21 and 23 February 1847, MF323, Reel 3, AIATSIS; Thomas 1861: 9.

25 Carr 2001b: 93.

26 Carr 2001a: 167-79; Cannon 1990: 205-217; Darian-Smith 2001: 180-92.

27 Schaffer 1995: 29-125.

28 Significant works in these areas include Fee 1974; Gilman 1985; Henningham 2000; Lepervanche 1989; Markus 1990; McGregor 1997; Russell 1994; Russett 1989; Stepan 1982; Walker 1999; White 1981.

29 Arden 1843: 67; Collins [1798] 1975, vol.1: 463; Curr 1883: 114-15, 120; Eyre 1845, vol.2: 319-22; Hamilton 1879: 31-32.

30 Barrallier 1975: 22-23; Collins [1798] 1975, vol.1: 463, 485-89, 498-99; Henderson 1832: 149, 153; Malcolm 1997: 59; Massie 1847; Sturt 1833: 55.

31 Arden 1843: 67; Cunningham 1827, vol.2: 19; Eyre 1845: 319-22. 
32 Bowler 1984: 90-92; Bowler 1989: 1-13; Schiebinger 1993: 84-100.

33 Adams 1995: 24-25; Brantlinger 2003: 157-60; Huhndorf 2001: 14-15, 20-22, 27-31, 56-58.

34 Merivale 1861 [1839-41]: 540.

35 Strzelecki 1845: 344-55.

36 Malthus [1798] 1986 vol.1: 18; Wokler 1995: 41.

37 Goodall 1996: 27; McGrath 1990: 193-94.

38 For example, JCS Handt, Journal, 13 August 1835: 12, WVP; Benjamin Hurst to CJ LaTrobe, 22 December 1841, AAR, VPRS4467, Reel 1; Benjamin Hurst to J McKenny, 8 March 1842, WMMS, Box 2, Mp2107; Threlkeld 1974, vol. 2: 227.

39 Fee 1974: 86-101.

40 Fee 1974: 92-93.

41 William Watson, Report 1: 1832: 3, WVP; William Watson to William Jowett, 17 January 1837: 1, WVP.

42 James Dredge, 'Journal' in Cannon (ed) 1983, vol. 2B: 712; Tyrell 1993: 152.

43 James Günther to Dandeson Coates, 30 November 1838: 2, WVP.

44 For example, Edward Stone Parker to GA Robinson, 1 April 1840 (Cannon (ed) 1983, vol.2B: 695); William Porter to Dandeson Coates, 22 February 1841: 4, WVP; Thomas, WTP, 31 October 1844, MF323, Reel 3; William Thomas to G. A Robinson, 1 March 1841, AAR, Reel 2; William Thomas to GA Robinson, 1 June 1846, AAR, VPRS4467, Reel 2; William Watson to Dandeson Coates, 31 December 1832: 2, WVP.

45 JCS Handt, Journal, 13 August 1835: 12, WVP; William Watson and JCS Handt 'Report on the Mission to the Aborigines of New Holland, 14 December 1833', WMMS, Box 2, Mp2107.

46 Bridges 1978: 778.

47 For discussion of protectors' and missionaries' relationships with police, see particularly Arkley 2000: 21-22, 326-29; Bridges 1978: 594-95, 642, 674; Campbell 1987: 206-7; Christie 1979: 83-84; Fels 1988: $95,141-50$.

48 For example, James Günther, Journal, 26 January 1838: 8, 11 April 1838: 3, 22 April 1838: 5-6, WVP; Robinson 1998b, vol. 4: 282; Charles Sievwright to GA Robinson, 1 June 1840 (Lakic and Wrench (eds), 1994: 131); Watson, Journal, 1 March 1834: 17, 29 December 1835: 11, WVP.

49 Cunningham, 1995: 48; Greven, 1977: 33-52; Robertson, 1988: 415; Sommerville, 1982: 125.

50 For example, Watson, Journal, 26 April 1833: 4-5, 16 March 1837: 17, WVP.

51 Watson, Journal, 6 November 1834: 7, WVP.

52 Arkley 2000: 141-42; Critchett 1990: 27-28.

53 Arkley 2000: 19.

54 Thomas, WTP, 15 November 1839, MF323, Reel 1.

55 Watson, Journal, 26 April 1833: 5, WVP.

56 Günther, Journal, 14 March 1838: 19-20, WVP.

57 Handt, Journal, 28 April 1833: 3, WVP.

58 Thomas, WTP, 24 August 1844, MF323, Reel 3.

59 Thomas, WTP, 24 and 25 August 1844, MF323, Reel 3.

60 Henry Fysche Gisbourne, quote in Gipps 1840 (1924): 618.

61 Watson, Journal, 16 February 1837: 15-17, WVP.

62 Watson, Journal, 29 December 1835: 11-12, WVP.

63 GM Langhorne to CJ LaTrobe, 15 October 1839 (Cannon (ed) 1983, vol. 2B: 508); GA Robinson, 1845 in Frauenfelder (ed) 1997: 53.

64 Bridges, 1978: 709; George Langhorne to Colonial Secretary, 31 December 1837 in Cannon (ed), 1982 , vol.2A: 208; Günther, Journal, 23 April 1838: 7, WVP. 